\title{
Antioxidant and Protease Activities of Seven Native Plant Sources
}

\author{
Y. Vasudeva Rao* and Merrine Raju
}

Dept. of Soil Science and Agricultural Chemistry, Institute of Agriculture, Visva-Bharati, Sriniketan, W.B. (731 236), India

\section{Article History}

Manuscript No. AR1646

Received in $4^{\text {th }}$ August, 2016

Received in revised form $28^{\text {th }}$ November, 2016

Accepted in final form $30^{\text {th }}$ November, 2016

\section{Correspondence to}

*E-mail: yvrao31@gmail.com

\section{Keywords}

Native plant sources, latex, DPPH, antioxidant activity, protease activity

\begin{abstract}
The in-vitro antioxidant activity and protease activity of the latex of different plant sources, namely Tabernaemontana divericata, Croton bonplandianum, Plumeria rubra, Nerium oleander, Cascabela thevetia, Alstonia scholaris, Allamanda cathartica were analysed. The antioxidant activity was analyzed using DPPH (11, dipenyl-2-picrylhydrazyl) reduction assay and protease activity was analyzed by the cleavage of milk protein, casein. From the results, it was observed that Croton bonplandianum latex has exhibited very strong and highest antioxidant activity (76 $\pm 5.4 \%)$ followed by Allamanda cathartica $(71 \pm 3.8 \%)$. Nerium oleander $(62 \pm 4.2 \%)$ and Plumeria rubra latexes $(58 \pm 2.9 \%)$ have showed good antioxidant activity. Cascabela thevetia (35 $4.4 \%)$ and Tabernaemontana divericata latexes $(28 \pm 3.0 \%)$ have showed moderate antioxidant activity. However, Alstonia scholaris latex has showed the least and negligible antioxidant activity $(0.19 \pm 0.05 \%)$. The protease activity was found to be significantly highest in the Tabernaemontana divericata latex $\left(4461.55 \pm 230 \mu \mathrm{g} \mathrm{ml}^{-1}\right)$ followed by Cascabela thevetia $(3307.7 \pm 284$ $\left.\mu \mathrm{g} \mathrm{ml}^{-1}\right)$. Good amount of the protease activity was found in Allamanda cathartica latex $\left(1205.15 \pm 155 \mu \mathrm{g} \mathrm{ml}^{-1}\right)$ followed by Croton bonplandianum $(923.1 \pm 213 \mu \mathrm{g}$ $\mathrm{ml}^{-1}$ ). Moderate amount of the protease activity was found in Nerium oleander (333.35 $\left.\pm 84 \mu \mathrm{g} \mathrm{ml}^{-1}\right)$ and Plumeria rubra latexes $\left(179.5 \pm 38 \mu \mathrm{g} \mathrm{ml}^{-1}\right)$. However, least protease activity was observed in Alstonia scholaris latex $\left(51.3 \pm 14 \mu \mathrm{g} \mathrm{ml}^{-1}\right)$. The results revealed that almost all plant latex samples except $A$. scholaris have showed from moderate to strong antioxidant and protease activities. $C$. bonplandianum latex has exhibited significantly highest antioxidant activity and $T$. divericata latex has exhibited significantly highest protease activity.
\end{abstract}

\section{Introduction}

Plant latex is a good source of pharmaceuticals, pesticides and immune allergens. It is an emulsion like sticky materials, from various plant parts after having a small tissue injury. In most plant species latex is come out as white glue from bark of plants. It is a complex mixture of important bio molecules such as of proteins, alkaloids, starch, sugars, oils, tannins, glycosides, resins, gums Phytosterols, Flavonoids, acetogenins and saponins (Thomas et al., 2008).

Latex is a sticky sap that flows out of some particular plants. It is milky fluid secreted by ducts of laticiferous tissues and seals wounds as it coagulates when discharged from those (Lewinsohn, 1991). It mainly flows inside laticifers including roots, stems, leaves and fruits of all flowering plants (Pickard, 2008). In most plants, latex colour is normally white, yellow, orange, or scarlet but some plant latex colour changes after an air exposure. In addition plant latex contains wide diversity of biological activities against bacteria, fungi, viruses, protozoan, nematodes, insects, and cancer and tumours. It used as disinfectant, anticoagulant, anti-inflammatory, antioxidant and ant proliferative agent that provides protection in wounds (Mesquita et al., 2005).

The molecular formula of latex is $\mathrm{C}_{3} \mathrm{H}_{3} \mathrm{~N}$ (carbon, hydrogen and nitrogen) and the constituents such as glycolipids, alkaloids, acids, laticifer proteins, acid phosphates from Euphorbia characias latex (DeMarino et al., 2008). Most of the research on latex and latex-bearing plants has been conducted for the use of the rubber processing industry and has been discussed in detail (D'Auzac et al., 1995). Latex shows an important role in plant-insect interactions. It is considered as analogous to animal venom; it contains cysteine proteases, which provide defense against herbivorous insects (Kitajima et al., 2010) and phytopathogenic fungi (Pintus et al., 2011). In this present study we have collected latex from seven native plant sources in our university campus and evaluated for antioxidant and 
protease activities.

\section{Materials and Methods}

A laboratory experiment was conducted to evaluate the antioxidative and protease activity from the latex sample collected from different indigenous plant species available at Visva-Bharati university campus during June-December 2015

\subsection{Sample collection}

Indigenous plant species, namely, Tabernaemontana divaricata (Apocynaceae), Plumeria rubra (Apocynaceae), Nerium oleander (Apocynaceae), Cascabela thevetia (Apocynaceae), Alstonia scholaris (Apocynaceae), Allamanda cathartica (Apocynaceae), Croton bonplandianum (Euphorbiaceae) were used for analysis. These plants have been identified by the Department of Botany, Visva-Bharati, Santiniketan, (India) and voucher specimen was deposited to the same department for reference. Plant latex is collected freshly between 09:30-11:00 AM before the start of the experiment. The latex samples were collected and used on the same day and were never preserved before the analysis. The twig of the plant was thoroughly cleaned with wet cotton and then tissue paper, a small scratch was made with a blade and the latex was collected into a micro tube. With these fresh latex samples all the experiments were conducted at Palli Siksha Bhavana (Institute of Agriculture), Visva-Bharati, Sriniketan .

\subsection{Determination of anti-oxidant activity}

The scavenging ability of the natural antioxidants of the plant extracts towards the stable free radical DPPH (1-1, dipenyl-2picrylhydrazyl) was measured by the method of DPPH assay (Mensor et al., 2001). $10 \mu 1$ of latex was taken into a clean test tube and diluted by addition of $1 \mathrm{ml}$ of phosphate buffer $(\mathrm{pH}=7.0)$, and to this $1 \mathrm{ml}$ of DPPH ( $0.4 \mathrm{mM}$ in ethanol) was added. The mixture was allowed to react at room temperature for 10 minutes. In the control tube no plant source was added, $1010 \mu \mathrm{l}$ of buffer and $1 \mathrm{ml}$ of DPPH was taken in the control tube. The discoloration of the purple colour was measured at $518 \mathrm{~nm}$ in a UV-Vis Spectrophotometer. The Anti-oxidant activity was calculated as follows.

Scavenging activity $(\%)=$ Control-Sample $\times 100$ Control $^{-1}$.

\subsection{Determination of protease activity}

Proteases hydrolyse protein (ex. Casein) into peptide fragments and amino acids. The blue colour developed under alkaline medium with Folin-Ciocalteau reagent (FC reagent) was measured at $700 \mathrm{~nm}$, and the proteolytic activity is calculated. The enzyme activity was expressed as $\mu \mathrm{g}$ of tyrosine liberated in $15 \mathrm{~min}$, at $37^{\circ} \mathrm{C}$, at $\mathrm{pH} 7, \mathrm{ml}^{-1}$ of enzyme (McDonald et al., 1965). Reaction was carried out in micro eppendorf tubes. 20 $\mu l$ of the latex sample was taken into each Eppendorf tube and diluted to $100 \mu 1$ with buffer, then $900 \mu 1$ of casein ( $1 \%$ dissolved in the phosphate buffer, $\mathrm{pH}=7$ ) was added to the tube. The mixture was incubated at room temperature for $15 \mathrm{~min}$ and at the end of this incubation; $1 \mathrm{ml}$ of trichloro acetic acid $(10 \%$ TCA in distilled water) was added to stop the reaction. Then the tubes were shaken thoroughly and centrifuged at $5000 \times \mathrm{g}$ for $15 \mathrm{~min}$. After centrifugation, $0.5 \mathrm{ml}$ of the supernatant was taken and transferred into a clean and dry glass test tube. To this $5 \mathrm{ml}$ of $0.5 \mathrm{M} \mathrm{NaOH}$ solution was added and mixed, then 0.5 $\mathrm{ml}$ of FC reagent was added to the tube and mixed thoroughly. The control reaction was carried out similarly except that the TCA was added to the latex prior to the addition of the substrate casein. The intensity if the blue colour developed was measured in a UV-Vis Spectrophotometer at $700 \mathrm{~nm}$. The protease activity was calculated from the standard graph prepared for tyrosine $\left(100 \mu \mathrm{g} \mathrm{ml}^{-1}\right)$ using phosphate buffer for blank. The enzyme activity is expressed as $\mu \mathrm{g}$ of tyrosine liberated in $15 \mathrm{~min} \mathrm{ml}^{-1}$ of latex.

Protease activity of plant sample $=\mathrm{T}-\mathrm{C} / \mathrm{S}-\mathrm{B} \times 50 \times 50 \times 2$, (where, $\mathrm{T}=$ Test; $\mathrm{C}=$ Control; $\mathrm{S}=$ Standard; $\mathrm{B}=\mathrm{Blank}$ ).

\section{Results and Discussion}

\subsection{Antioxidant activity}

The antioxidant activity of different plant latex extracts was determined using ethanol solution of DPPH reagent. DPPH is a stable free radical. The effect of an antioxidant on DPPH radical scavenging is due to their hydrogen donating ability or free radical scavenging activity (Sudha et al., 2011). When a solution of DPPH is mixed to the substance that can donate a hydrogen atom, then this gives rise to the reduced form diphenylpicryl hydrazine which loss of its violet colour (Rajan et al., 2011). The DPPH test gives the information on the reactivity of the test compounds with a stable free radical scavenging activity. DPPH gives a strong absorption band at $517 \mathrm{~nm}$ in visible region (Naskar et al., 2011). When the odd electron becomes paired and free radical scavenger absorb, it reduces the DPPH solution and is decolorized. The colour changes from deep violet to light yellow.

From the results (Figure 1), it was observed that Croton bonplandianum latex has exhibited very strong and highest antioxidant activity ( $76 \pm 5.4 \%)$. It was observed that the violet color of the DPPH solution is disappeared immediately (within a second) after the addition of the $C$. bonplandianum plant latex to the DPPH solution. This indicates that the latex of C. bonplandianum was a rich source of molecules with very strong antioxidant activity. Latex from Allamanda cathartica plant source also showed very strong antioxidant activity (71 $\pm 3.8 \%)$. Latex of $A$. cathartica also shown to be a rich source of molecules with strong antioxidant activity. However, the antioxidant activity of $A$. cathartica latex is little lesser 


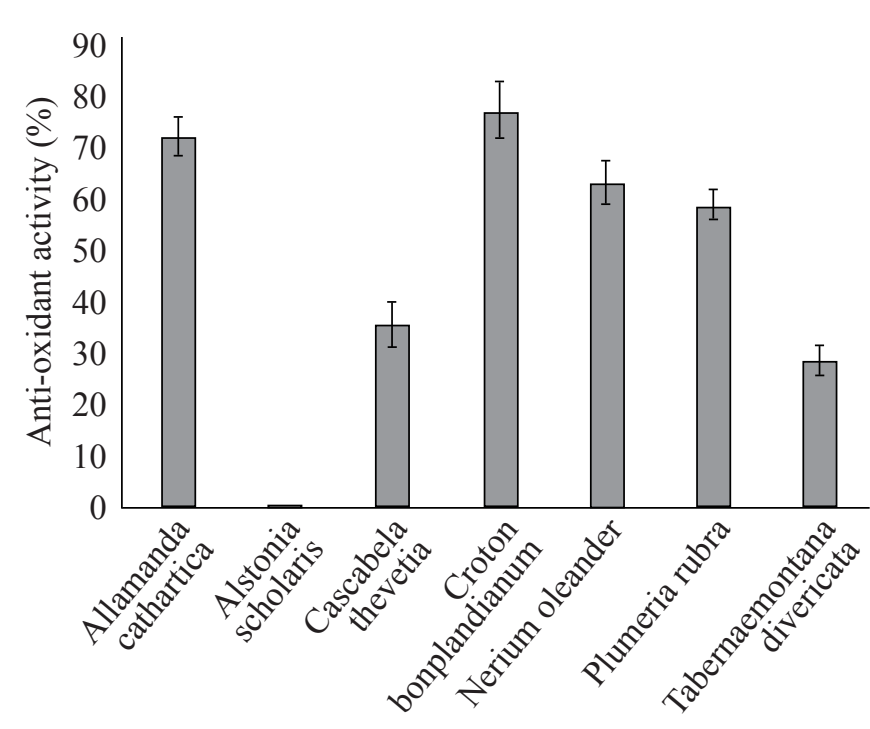

Figure 1: Anti-oxidant activity of the latex from seven native plant sources

than the $C$. bonplandianum. Latex from Nerium oleander plant latex has showed good antioxidant activity $(62 \pm 4.2 \%)$ and Plumeria rubra plant latex also has showed good antioxidant activity (58 $2.9 \%)$. However, the antioxidant activity of these two plant samples was very lesser than C. bonplandianum and A. cathartica. The latex from Cascabela thevetia (35 $\pm 4.4 \%)$ and Tabernaemontana divericata (28 $3.0 \%$ ) plant sources has showed moderate antioxidant activity. This indicates that the latex of these plants do have moderate and measurable amounts of antioxidant molecules. Latex from Alstonia scholaris plant source has showed the least and negligible antioxidant activity $(0.19 \pm 0.05 \%)$, indicating that this plant sample doesn't have any molecules with anti-oxidant activity.

\subsection{Protease activity}

Proteases occur naturally in living organisms. Growth and development in all organisms occur as a result of an overall balance between protein synthesis and proteolysis. Commercially, proteolytic enzymes from the plant sources have received special attention because of their broad substrate specificity as well as activity in wide range of $\mathrm{pH}$ and temperature (Vidyalakshmi and Selvi, 2013). Proteases are effective in removing damaged and infected tissues from wounds and thus play an important role in the wound healing process. Proteases from various sources such as plant, microbes, maggots and animals were found to be useful in wound debridement (Walsh, 2003).

In this present study we have tested seven native plant sources, and from the results (Figure 2), it was observed that the proteases activity was also found in the latex of different plants tested. Among the plants tested, the protease activity was found to be significantly highest in the Tabernaemontana divericata latex $\left(4461.55 \pm 230 \mu \mathrm{g} \mathrm{ml}^{-1}\right)$, and Cascabela thevetia latex also showed higher protease activity $\left(3307.7 \pm 284 \mu \mathrm{g} \mathrm{ml}^{-1}\right)$. Good amount of the protease activity was found in Allamanda cathartica latex $\left(1205.15 \pm 155 \mathrm{gg} \mathrm{ml}^{-1}\right)$ followed by Croton bonplandianum latex $\left(923.1 \pm 213 \mu \mathrm{g} \mathrm{ml}^{-1}\right)$. Moderate amount of the protease activity was found in the latexes of Nerium oleander $\left(333.35 \pm 84 \mu \mathrm{g} \mathrm{ml}^{-1}\right)$ and Plumeria rubra $(179.5 \pm 38$

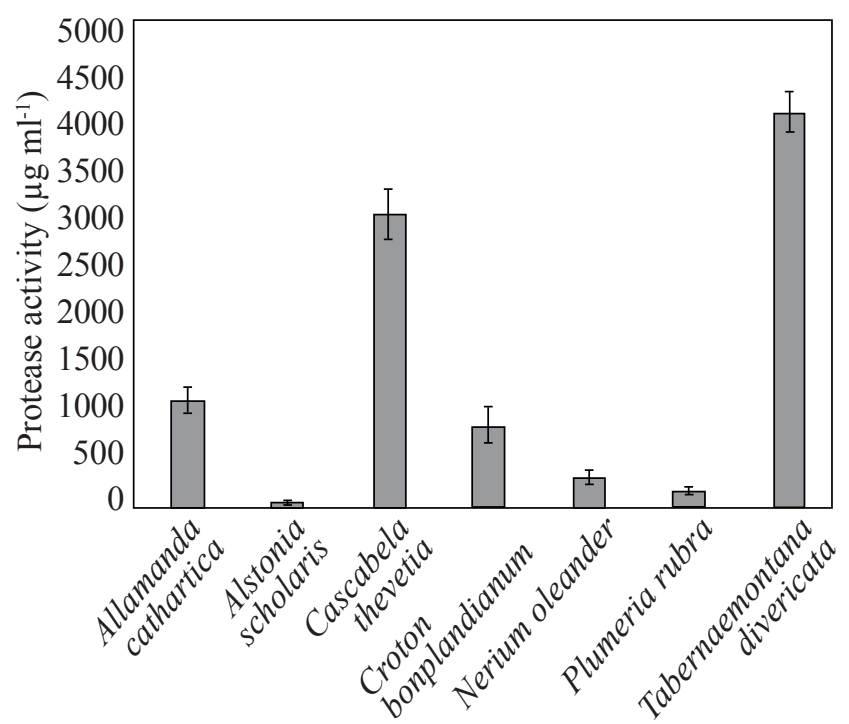

Figure 2: Protease activity of the latex from seven native plant sources

$\mu \mathrm{g} \mathrm{ml}^{-1}$. Among all the plants tested, least protease activity was observed in the latex of Alstonia scholaris (51.3 $\left.\pm 14 \mu \mathrm{g} \mathrm{ml}^{-1}\right)$.

Plants sources play an important role due to secondary metabolites and responsible for several biological activities in humans as well as animals. It is also used to treat variety of diseases. These medicinal plants are not only providing traditional and ethnic medicine but it promising for highly effective bioactive molecules. Plant latex contains hazardous chemical substances that cause allergic reactions and induce immediate-type hypersensitivity in them. In addition plant latex contains wide diversity of bioactive chemicals which showed different biological activities such as anti-carcinogenic, antiproliferative, anti-inflammatory, vasodilatory, anti-oxidant, anti-microbial, anti-parasitic and insecticidal (Mesquita et al., 2005).

The present study showed that latex of the plant sources are rich sources of bioactive molecules such as anti-oxidants and proteases. Good amounts of molecules having antioxidant activity is present in all the plant latex samples tested $(>25 \%)$. Similarly, good amount of proteases are present in all plant latex samples tested $\left(>150 \mathrm{mg} \mathrm{ml}^{-1}\right)$. However, Alstonia scholaris plant latex did exhibit poor amount of both antioxidant activity and protease activity (Figures 1 and 2). All assays were carried out at room temperature and at $\mathrm{pH}=7$. And it may be that this 
working condition is not suitable for the activity of Alstonia scholaris, and hence, could not show any of the activities tested. Apart from antioxidant and protease activities, various research studies have shown that the plant sources that were tested in this present research work also possess different bioactivities.

Methanolic flower extracts of Plumeria Alba and P. Rubra were tested for in vitro antioxidant potential, cytotoxicity and hypolipidemic activities. From the results it was concluded that Plumerias pecies could be a new source of drugs for the treatment of colon cancer and hyperlipidemic conditions due to higher antioxidant potential and phenolic content (Rahman et al., 2014). P. rubra leaves are used in the care of sores and made into soothing infusion (Pauline, 2000). Antitumor properties of twigs extract of Croton bonplandianum was proven using potato disc and radish seed bioassays. Tumor formation ability of Agrobacterium was distinctly inhibited on potato disc in presence of methanol extract. Tumor inhibition was increased with the increasing of concentrations of plant extract. Decreasing the root length and percentage of seed germination during radish seed bioassays further confirmed the anti-tumor properties of $C$. bonplandianum. It was concluded that the bioactive compound of this plant may play an important role in developing antitumor drugs for human beings, as there is a similarity between human and plant tumor formation mechanism (Islam et al., 2010). Allamanda cathartica has been used to treat liver tumors (Schmidt et al., 2006) jaundice, splenomegaly, and malaria. In analyses, some species have shown some activity against carcinoma cells, pathogenic fungi, and HIV (Haron et al., 2013). Tabernaemontana divaricate possess a wide range of therapeutic activities like alexipharmic, emmenagogue, astringent, anticancer, hepatoprotective, aphrodisiac, digestible, purgative, antibacterial etc. The chloroform and alcoholic leaf extracts showed inhibitory potential against both gram positive and negative bacteria when compared to standard drug Ampicillin at $10 \mu \mathrm{g}$ level. Hence, leaf extracts of Tabernaemontana divaricate can replace safely to standard synthetic antimicrobial agents (Raj and Balasubramaniam, 2011). Methanol, aqueous and total alkaloid extracts from the trunk bark of Alstonia scholaris (L.) R. Br. (Apocynaceae), growing in northeast India was evaluated and found to possess in vitro antibacterial activity (Hussain et al., 2010). Different solvent extracts of Nerium oleander was evaluated and found to possess significant in vitro antibacterial activity (Suganya et al., 2012). The flowers of Cascabela thevetia was evaluated and found to possess significant in vitro anticancer activity, thereby explaining the use of this plant in the traditional system of medicine (Solomon et al., 2016).

\section{Conclusion}

Latex samples from seven native plant sources were collected and tested for antioxidant and protease activities. Results revealed that except Alstonia scholaris, all six plant latex samples have showed moderate to strong antioxidant and protease activities. Croton bonplandianum latex has exhibited very strong and significantly highest antioxidant activity whereas Tabernaemontana divericata latex has exhibited strong and significantly highest protease activity indicating their importance and bioactive role in the immunity of the plants.

\section{References}

D’Auzac, J., Prevot, J.C., Jacob, J.L., 1995. What's new about lutoids? A vacuolar system model from Hevea latex. Plant Physiology and Biochemistry 33(6), 765-777.

DeMarino, S., Gala, F., Zollo, F., Vitalini, S., Fico, G., Visioli, F., 2008. Identification of minor secondary metabolites from the latex of Croton lechleri (Muell-Arg) and evaluation of their antioxidant activity molecules. Multidisciplinary Digital Publishing Institute 13, 1219-29.

Haron, F.F., 2013. Bioassay-guided isolation of antifungal plumericin from Allamanda species (Apocynaceae). Journal of Biological Sciences 13, 158-62.

Hussain, A., Zaman, M.K., Ramteke, A.M., 2010. Antibacterial activity of trunk and bark of Alstonia scholaris. Asian Journal of Pharmaceutical and Clinical Research 3(4), 46-47.

Islam, M.S., Rahman, M.M., Rahman, M.A., Qayum, M.A., Alam, M.F., 2010. In vitro evaluation of Croton bonplandianum Baill. as potential antitumor properties using Agrobacterium tumefaciens. Journal of Agricultural Technology 6(1), 79-86.

Kitajima, S., Kamei, K., Taketani, S., Yamaguchi, M., Kawai, F., Komatsu, A., 2010. Two chitinase-like proteins abundantly accumulated in latex of mulberry show insecticidal activity. BMC Biochemistry 11, 6-11.

Lewinsohn, T.M., 1991. The geographical distribution of plant latex. Chemo Ecology 2, 64-68.

McDonald, C.E., Chen, L.L., 1965. The Lowry modification of the Folin reagent for determination of Proteinase activity. Analytical Biochemistry 10,175-177.

Mensor, L.L., Menezes, F.S., Leitao, G.G., Reis, A.S., Santos, T.C., Coube, C.S., Leitao, S.G., 2001. Screening of Brazilian plant extracts for antioxidant activity by the use of DPPH free radical method. Phytotheraphy Research 15,127-130.

Mesquita, M.L., Desrivot, J., Bories, C., Fournet, A., Paula, J.E., Grellier, P., 2005. Antileishmanial and trypanocidal activity of Brazilian Cerrado plants. Memorias do Instituto Oswaldo Cruz 100 (7), 783-7.

Naskar, S., Mazumder, U.K., Pramanik, G., Bala, A., Haldar, 
P.K., Islam, A., Gupta, M., 2011. Comparative in vitro antioxidant activity of different parts of Cocos nucifera (Linn.) on reactive oxygen and nitrogen species. Indian Journal of Pharmaceutical Sciences 3(3), 104-107.

Pauline, D.P., 2000. Plants Used in Cambodia, printed by Imprimerie Olympic. In: Phnom Penh Henary, H.A., Kurzrock, R., Falchook, G.S., 2011. "Final Results of a First-in-Human Phase 1 Trial of PBI-05204 and Inhibitor of AKT, FGF-2, NF-Kb and P70S6K in Advanced Cancer Patients". Journal of Clinical Oncology (supplement, abstract 3023).

Pickard, W.F., 2008. Laticifers and secretory ducts: Two other tube systems in plants. New Phytologist 177, 877-88.

Pintus, F., Spano, D., Medda, R., Flori, S.G., 2011. Calcium ions and a secreted peroxidise in Euphorbia characias latex are made for each other. Protein Journal 30, 115-23.

Rahman, H., Reddy, V.B., Ghosh, S., Mistry, S.K., Pant, G., Sibi, G., 2014. Antioxidant, cytotoxic and hypolipidemic activities of Plumeria alba L. and Plumeria rubra L. American Journal of Life Sciences 2(6-1), 11-15.

Raj, C.N., Balasubramaniam, A., 2011. Pharmacognostic and Antimicrobial Studies of the leaves of Tabernaemontana divaricate R.BR. Pharmacology Online 2, 1171-1177.

Rajan, S., Mahalakshmi, S., Deepa, V.M., Sathya, K., Shajitha, S., Thirunalasundari, T., 2011. Antioxidant potentials of Punica granatum fruit rind extracts. Indian Journal of Phamaceutical Science 3(3), 82-88.

Schmidt, D.F.N., Yunes, R.A., Schaab, E.H., Malheiros,
A., CechinelFilho, V., Franchi, G.C.Jr., Nowill, A.E., Cardoso, A.A., Yunes, J., 2006. Evaluation of the anti-proliferative effects the extracts of Allamanda blanchetti and A. schottii on the growth of leukemic and endothelial cells. International Journal of Pharmacy and Pharmaceutical Sciences 9(2), 200-08.

Solomon, S., Muruganantham, N., Senthamilselvi, M.M., 2016. Anticancer activity of Cascabela thevetia (Flowers) against Human Liver Cancer. International Journal of Pharma Sciences 6(4), 1598-1600.

Sudha, G., Sangeetha, P.M., Indhushree, R., Vadivukkarasi, S., 2011. Antioxidant activity of ripe pepino fruit. International Journal of Pharmacy and Pharmaceutical Sciences 3(3), 257-260.

Suganya, R.S., Priya, K., Roxy, B.S., 2012. Phytochemical screening and antibacterial activity from Nerium oleander and evaluate their plant mediated nanoparticle synthesis. International Research Journal of Pharmacy 3(5), 285-287.

Thomas, R., Sah, N.K., Sharma, P.B., 2008. Therapeutic biology of Jatropha curcas. A mini review-Current Pharmaceutical Biotechnology 9(4), 315-24.

Vidyalakshmi, A., Selvi, E., 2013. Protease Activity of Floral Extracts of Jasminum grandiflorum L., a Wound Healing Herb. Journal of Medicinal Plant Studies 1(4), 11-15.

Walsh, G., 2003. Biopharmaceuticals: Biochemistry and Biotechnology. $2^{\text {nd }}$ Edition, John Wiley and Sons Ltd. England, 2003, 398. 